\title{
Lifestyle and diabetes mellitus in cats and dogs
}

\author{
Charlotte Bjørnvad \\ From Animal Obesity - causes, consequences and comparative aspects \\ Uppsala, Sweden. 14-16 June 2015
}

In westernised countries, obesity is the most commonly diagnosed nutritional disorder in dogs and cats, with an estimated prevalence of between $22 \%$ and $44 \%$ in investigated populations. In humans, it is well established that obesity predisposes to lifestyle-related diseases such as type 2 diabetes mellitus and atherosclerosis. Dogs and cats seem less prone to developing atherosclerosis compared with humans, while diabetes is a relatively common endocrine disease in both species. The high prevalence of obesity in pet dogs and cats is believed to be multifactorial, often relating to lifestyle and the fact that pets have moved from being working animals to becoming close family members. Influencing factors include neutering, inactivity, genetic predisposition as well as factors such as interaction with owners through feeding/treats and the owners lacking recognition of their pets being overweight. As in humans, obesity causes insulin resistance and impaired glucose metabolism in cats and dogs. In cats, this may progress into feline diabetes because long-term elevated insulin demands together with obesity-related metabolic alterations result in destruction of the beta cells - through mechanisms similar to development of human type 2 diabetes mellitus. In dogs, the pancreas seems to better cope with increasing demands for insulin production and type 2-like diabetes seldom develops. Obesity may however, still predispose for diabetes in dogs. A possible explanation could be that obese dogs are at risk of developing pancreatitis as a frequent consequence of pancreatitis in dogs is inflammation-mediated destruction of the beta cells.

Published: 25 September 2015

Correspondence: crb@sund.ku.dk

Department of Veterinary Clinical and Animal Sciences, University of Copenhagen, Copenhagen, Denmark

C Biomed Central

(c) 2015 Biørnvad This is an Open Access article distributed under the terms of the Creative Commons Attribution License (http:// creativecommons.org/licenses/by/4.0), which permits unrestricted use, distribution, and reproduction in any medium, provided the original work is properly cited. The Creative Commons Public Domain Dedication waiver (http://creativecommons.org/publicdomain/ zero/1.0/) applies to the data made available in this article, unless otherwise stated.
doi:10.1186/1751-0147-57-S1-K4

Cite this article as: Bjørnvad: Lifestyle and diabetes mellitus in cats and

dogs. Acta Veterinaria Scandinavica 2015 57(Suppl 1):K4. and take full advantage of:

- Convenient online submission

- Thorough peer review

- No space constraints or color figure charges

- Immediate publication on acceptance

- Inclusion in PubMed, CAS, Scopus and Google Scholar

- Research which is freely available for redistribution 